\title{
パツドー有機溶剂蒸熱処理によるポリエステル 織物の染色とその固着機構
}

福井大学工学部 清水融・堀照夫 田作寿楎 ${ }^{* 1}$. 今沢重英 ${ }^{* 2}$

\section{DYEING OF POLYESTER FABRIC BY PAD-SOLVENT STEAMING METHOD AND ITS MECHANISM OF DYE FIXATION}

\author{
By Toru Shimizu, Teruo Hori, Hisateru Tasaku *1 \\ and Juei Imazawa*2
}

(Department of Fibres and Colour Chemistry, Fukui University, 910 Fukui, Bunkyo 3-9-1)

\begin{abstract}
A new pad-steam dyeing process using organic solvents has been developed. 1-Aminoanthraquinone or 1,4-diaminoanthraquinone padded on the poly(ethylen terephthalate) fabrics could be fixed in high yield for a short time steaming with saturated organic vapour such as perclene and butanol-perclene mixture. The characteristic of fixation curves was compared with those of normal dip dyeing, and it was revealed that the dye padded on the fabric was fixed through three steps; the condensation of solvent on the fabric from vapour phase, the dissolution of dye in the condensed solvent and the dye diffusion into fabric from "very short liquor" formed on the fabric.

The steaming with $\mathrm{N}, \mathrm{N}$-dimethylformamide, which swells the polyester fabrics remarkedly and dissolves easily the disperse dyes on the fabrics, gives insufficient fixation of the dye on the fabrics. However, the practical fixation with high yield could be obtained through heat treatment for a short time after the solvent steaming.
\end{abstract}

(Received October 23, 1981)

\section{1. 緒 \\ 言}

分散染料をパッドしたり，あるいは捺染糊印捺した ポリエステル (PET) 織物の飽和水蒸気に上る蒸熱処理 はサーモゾルあるいは過熱水蒸気処理に較べてすぐれた 固着結果を得るが，高代蒸熱装置の使用が必要である。 し加るに適当な有機溶媒を使用する之常圧で短時間の蒸 熱で良好な固着が得られ，溶剤の回収拉よび毒性などを 考慮したクローズド系が装置的に解决できれい゙固着法上 して極めて有利となる。

\footnotetext{
${ }^{* 1}$ 現在の所属：北陸化工(蛛)，福井県鯖江市 Present address : Hokuriku Kako Co. Ltd., 916 Sabae

*2 琵在の所属：福井県農業協同租合，福井市 Present address: Fukui Prefectural Agricultural Cooperative Association, 910 Fukui
}

F. Sommら”はテトラクロロエチレン(PER)の過熱 蒸気で分散染料をPET織物红固着させる Salvafix 法在 発表し, $140 \sim 180^{\circ} \mathrm{C}$ の過熱PER蒸気により1 分間の処 理で固着が可能であると報告している。

本報告は有機溶剂の飽和蒸気処理に上るPET織物の 迅速固着法の実験例寺すと其に，溶剤飽和蒸気䎲よる パッド織物上の染料の固着速度，固着率および飽和固着 量を測定した。そして染料の溶剂への溶解度およびこの 溶液からの飽和染着量を測定し，これらの結果をもとに 蒸熱処理による固着機檴を解明した。

\section{2. 実験}

2.1 試 料

PET織物：100\% PET織維のタフタおよびクレープ

デシン織物を常法で精練し試料に供した。

染 料: 1.4-ジアミノアントラキノン(1.4-DAAQ) 
および1ーアミノアントラキノン(1-AAQ)の市販1 級

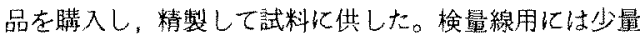
含末れる色装不純物を力ラムクロマトグラフィーにより 分離除去し，ベンゼンで再結晶した融点 $268^{\circ} \mathrm{C}$ 和よび 252 Cのものを用いた。パッディングおよび染色用にはベン ゼンからの雨結晶精製品を使用した。

溶 剂: 市販1級品を蒸留して用いた。テトラクロロ エチレン(PER)のみは市販品をそのまま使用した。

2.2 染料のパッド法，蒸熱法および付着量と固 着電の測定

染料をジメチルホルムアミド(DMF)に溶解したパッ ド液中にPET織物を 5 秒間浸漬後，ロールにテフロン コートしたパッダで絞り，30 C の室温で風乾させた。付 着染料量は士2.5\%の誤差内で均一に付着できた。

蒸熱法，または付著染料量 $D_{\mathbf{p}}^{0}$ ，末固着染料扣よで固 著染料量 $D_{\mathrm{F}}$ の湘定法は既法 ${ }^{2 \sim 9)}$ 上问様のち法で行なっ t。

2.3 PET 織物の漫染法による平衡染着量の測 定

$100^{\circ} \mathrm{C}$ 以下での溶剂からの染色は $100 \mathrm{ml}$ の䋖口染色ビ ンを用いて乍なった。染液は時々新しい液之交換して， 限浴条件を保ちながら平衡染色した。染色物は乾燥後， 末固着染料をアセトン $(80 \%$ 水溶液 $)$ で流出し，風乾後 mータレゾールに溶解し，此色法で染着量を求姉た110 ${ }^{\circ} \mathrm{C}$ 以てでHi-Di染色機(草産業)用い平衡まで染色 Lt。

\section{4. 染料溶解度の测定}

分散染料の溶剂に対する溶解度は南後》の方法に従い 定温で長時間放疅した末溶解染料を含む溶液の上澄液を G4グラスフィルターを通してろ過採液し、比色法によ

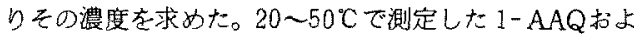
び1４－DAAQのPERに対する溶解度は南後の測定值 とはは一致し，乙れら加求如溶解熱加ら90〜110 C の溶解度を算出した。また1-AAQについては90およ び，100学で上記上同様な方法で直接溶解度を測定した が，これらの值は計算值より約 $15 \%$ 程大きな值を示した。 結果を表 4 亿示す。

\section{3. 結果と考察}

\section{1 䕩熱処理および固着法の決定}

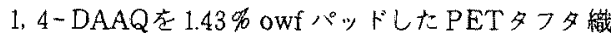
物を璉々の温度のPET飽和蒸気中で処理したときの固 着曲楾を图 1K示す。蒸熱鼬度の上昇と共に固着速度书 よび固着量は增加する。蒸熱溶剤の種類を変えて $110^{\circ} \mathrm{C}$ で固着速度を比較した結果の 1 部を図 2 に示す。DMF および 1，1，2-トリクロロエタン(TCE)の如くPET緎

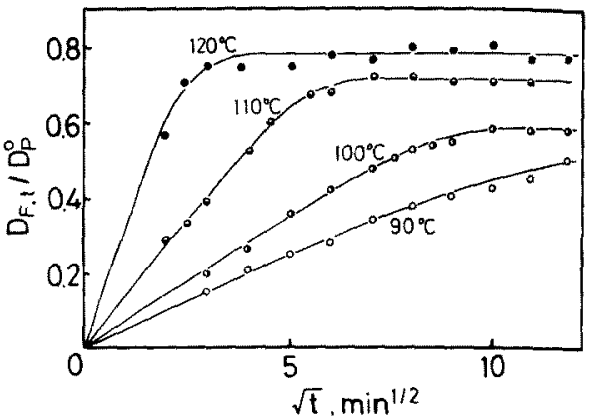

Fig. 1 Reduced fixation curves for 1,4-DAAQ padded on PET fabric (taffeta) by steaming with saturated PER vapour at various temperatures.

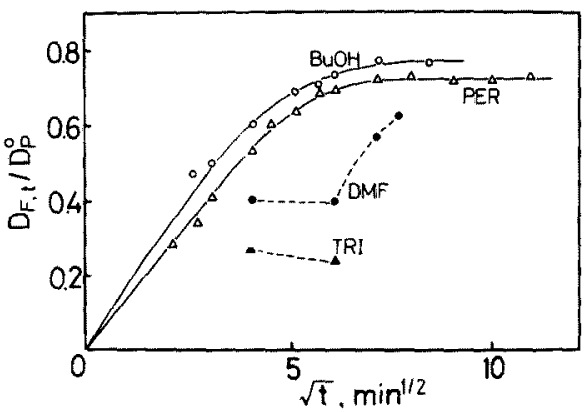

Fig. 2 Reduced fixation curves for 1,4-DAAQ padded on $P E T$ fabric by steaming with various solvent vapours at $110^{\circ} \mathrm{C}$.

維に対し膨潤性の大きな溶剂では固着率が低く、また測 定值のバラッキが大きく固着速度は測定できなかった。 しれらの溶剂では処理時閻亡ともに織物の収縮率か增し， 16 分の処理でDMFでは $3.5 \%$ ，TCEでは $9.7 \%$ の取縮 率を示した。DMF蒸熱などでは蒸熱後アセトンで未固 着染料を抽出する際，織維内に残留する溶剂が染料の脱 着を援助するため固着量にバラッキが生ずると考え，蒸 熱观理後，溶剂蒸発させ，かつ，熱により非晶の膨灌

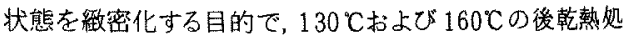
理を行なった。その結果，表1亿示す如く，固着率は著 しく向上した。そしてDMFの $110^{\circ} \mathrm{C}$ 飽和蒸気で1分間 蒸熱処理し，その後，160员で 1 分間の乾熱処理を加え る事により97\%の固着率が得られ，水洗を不要とする迅 速で有効な固着法が見出された。次にこれらの蒸熱処理 による固着機構の検討を更に詳細に行なった。

\section{2 固着速度および飽和固着量の測定結果}

各種染料濃度のDMF溶液をPETクレープデシン維 物にパッドし，付着染料濃度 $D_{\mathrm{P}}^{\circ}$ の異なる蒸熱処理用試 
Table 1 Effect of dry-heat treatment after solvent steaming on dye fixation.

\begin{tabular}{|c|c|c|c|c|c|c|}
\hline \multirow[b]{2}{*}{ Solvent } & \multicolumn{2}{|c|}{ Steaming } & \multicolumn{2}{|c|}{ Aftert reatment } & \multirow{2}{*}{$\begin{array}{c}\text { Fixation } \\
\text { Yield } \\
(\not /)\end{array}$} & \multirow{2}{*}{$\begin{array}{c}\text { Shrinkage } \\
(\%)\end{array}$} \\
\hline & $\begin{array}{l}\text { Temp. } \\
\text { ( }{ }^{\circ} \text { ) }\end{array}$ & $\begin{array}{l}\text { Time } \\
(\min )\end{array}$ & $\begin{array}{c}\text { Temp } \\
\text { (C) }\end{array}$ & $\begin{array}{l}\text { Time } \\
\text { (min) }\end{array}$ & & \\
\hline blank & - & - & 130 & 1 & 18 & 1.0 \\
\hline blank & - & - & 160 & 1 & 32 & 0.0 \\
\hline DMF & 110 & 16 & - & - & 39 & 1.3 \\
\hline DMF & 110 & 1 & 130 & 1 & 82.5 & 3.5 \\
\hline DMF & 110 & 1 & 160 & 1 & 97 & 2.5 \\
\hline TCE & 110 & 16 & - & - & 23 & 9.7 \\
\hline TCE & 110 & 1 & 130 & 1 & 92 & 7.3 \\
\hline TCE & 110 & 1 & 160 & 1 & 96 & 7.3 \\
\hline $\mathrm{BuOH}-\mathrm{PER}$ & 110 & 7 & - & - & 69 & 1.2 \\
\hline $\mathrm{BuOH}-\mathrm{PER}$ & 110 & 7 & 160 & 1 & 94 & 1.2 \\
\hline $\mathrm{BuOH}-\mathrm{TCE}$ & 110 & 7 & - & - & 60 & 2.4 \\
\hline $\mathrm{BuOH}-\mathrm{TCE}$ & 110 & 7 & 160 & 1 & 85 & 2.5 \\
\hline $\mathrm{BuOH}-\mathrm{PER}$ & 110 & 25 & - & - & 77 & 1.2 \\
\hline $\mathrm{BuOH}-\mathrm{PER}$ & 110 & 25 & 160 & 1 & 98 & 1.3 \\
\hline $\mathrm{BuOH}-\mathrm{TCE}$ & 110 & 25 & - & 一 & 75 & 25 \\
\hline $\mathrm{BuOH}-\mathrm{TCE}$ & 110 & 25 & 160 & 1 & 97 & 2.5 \\
\hline
\end{tabular}

DMF : $\mathrm{N}, \mathrm{N}$-dimethylformamide

TCE : 1,1,2-trichloroethane PER : 1,1,2,2-tetrachloroethylene BuOH: $n$-buthanol

料を作成した。これらを所定温度の溶剂飽和蒸気中で各 種時間処理し， $t$ 時間での染料の固着量 $D_{\mathrm{F}, t}$ を測定した。 結果の一例として，1４４-DAAQ パッド織物を $100{ }^{\circ} \mathrm{C} の$ PER 飽和蒸気中で処理したときの固着速度曲線を図 3 に示す。さらに図 3 の綎軸を $D_{\mathrm{F}, t}$ の平衡固着量 $[D]_{\mathrm{F}}$ に 対する比化直しプロットした結果在图 4 亿示す。1一 $\mathrm{AAQR}$ 対して溶剂および温度を变えて行なった場合も 類似の結果が得られた。図了より $D_{\mathrm{P}}^{\circ}$ に対する $[D]_{\mathrm{F}}$ の 関係，すなわち固着等温線を作ることができる。ここで は1ーAAQパッド織物を $90^{\circ} \mathrm{C}$ 放よひ $100 \mathrm{C}$ ○ PER飽和

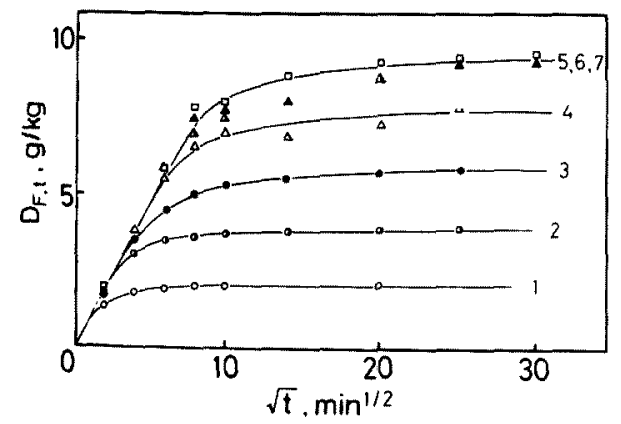

Fig. 3 Fixation curves for 1,4-DAAQ padded on PET fabric by steaming with saturated PER vapour at $100^{\circ} \mathrm{C}$ (Numbers on curves are sample number corresponding to those shown in Table 2).

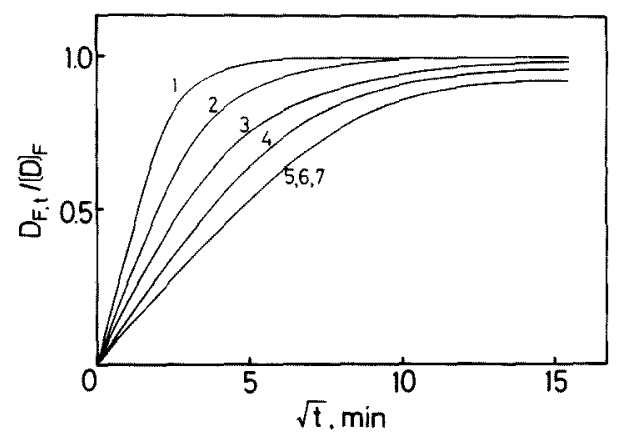

Fig. 4 Reduced fixation curves for 1,4-DAAQ padded on PET fabric by steaming with saturated PER vapor at $100{ }^{\circ} \mathrm{C}$ (Numbers on curves are sample number).

蒸気中で同様に処理した結果から得られた固着等温線を 示す(図 5)。図より明らかなように, $D_{\mathrm{P}}^{\circ}$ が增すと $[D]_{\mathrm{F}}$ は增加するが ある $D_{\mathrm{P}}^{\mathrm{o}}$ 以上で $(D)_{\mathrm{F}}$ は一定値となる。 この値は飽和固着量 $(D)_{\mathrm{F}}^{\mathrm{Sat}}$ であるが，各々の条件で得 られた $[D]_{F}^{\text {Sat }}$ の値を表 3 亿示す。

図3で固着初期には $D_{\mathrm{P}}^{\circ}$ の值にかかわらず次式が成立 する。

$$
D_{\mathrm{F}, t}=k_{0} t^{\mathrm{3} / 2}
$$

また，四4では固着初期に各々の $D_{\mathrm{P}}^{\circ}$ に対し(2)式が 成立する。 


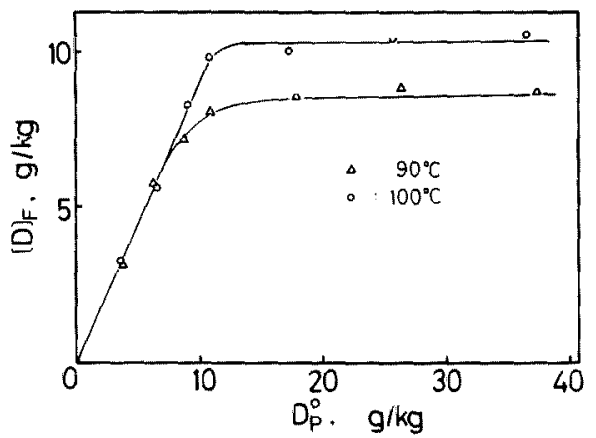

Fig. 5 Relation between amount of dye padded on fabric and equilibrium amount of dye fixed for the case of 1-AAQ.

$$
D_{F, t} /(D)_{\mathrm{F}}=k^{\prime} t^{1 / 2}
$$

これらの結果加ら求めた长の值は表 2 に示すが， $k^{\prime}$ は $D_{\mathrm{P}}^{\circ}$ の増加と其に减少し，No.5以降では一定檤とな る。表 3 より 1.4-DAAQOPERに对する $(D]_{F}^{\text {Sat }}$ $9.28 \mathrm{~g} / \mathrm{kg}$ であり，No.5 以降 $D_{\mathrm{p}}^{\circ}$ はこの值よりはるか⿰ 大きい。乙のような条件下では，屯し染料の溶解速度が
速ければ，織物に凝㜚または吸収された溶剤が付着染料 を直ちに溶解度まで溶解し，溶解された染料は餲和溶液 の無限染浴条件下で䋘維内部に拡散，固着される蒸熱固 着機構が考元られる。従って，図 3 はMcGregor ${ }^{\natural)}$ の指 摘する transtional kineticの良い例であろう。すなわ ち，蒸熱間に染浴が䬶和溶液から不飽和溶掖に移るまで は速度曲線はすべて飽和溶液の無限染浴加らの“Master curve”上にのり，染浴が不飽和に移行するとその 速度曲線使平方向に曲り始める。さらにN 0.5 以降で は最後まで飽和溶液の条件下で应散が進行するであるう。 それ故，ての速度曲線には䋞維を円筒体と考えた算限浴 下での搪散式(Hill 式)が適用でき，との式より求めたみ かけの拡散係数を表 2 の最後の欗に示した。また，阴筒 状基兵であっても，拡散の初期に対しては平板に対する 次の近似式が良く適用される。

$$
D_{\mathrm{F}, t} /[D]_{\mathrm{F}}=2(K t / \pi)^{\mathrm{V} / 2}
$$

ここで，Kは拉散係数を平板の厚さの半分(ことでは， 円筒の半往)の 2 乗で割った值である。

あし，先に仮定した上うに，蒸熱時の染料の溶解速度 が拡散速度に比べ著しく速いなら，固着初期ではHillの

Table 2 Kinetic data for fixation of 1,4-DAAQ padded on PET-fabric by steaming with saturated PER-vapour at $100^{\circ} \mathrm{C}$.

\begin{tabular}{ccccc}
$\begin{array}{c}\text { No. of } \\
\text { padded fabric }\end{array}$ & $\begin{array}{c}D_{\mathrm{P}}^{\circ}{ }^{1)} \\
(\mathrm{g} / \mathrm{kg})\end{array}$ & $\begin{array}{c}\left(t_{\mathrm{f}}\right)_{\mathrm{h}}{ }^{2} \\
(\mathrm{~min})\end{array}$ & $\begin{array}{c}k^{\prime 3} \\
\left(\mathrm{~min}^{1 / 2}\right)\end{array}$ & $\begin{array}{c}D^{4)} \\
\left(\mathrm{cm}^{2} / \mathrm{sec}^{3}\right)\end{array}$ \\
\hline 1 & 1.95 & 1.7 & 0.36 & - \\
2 & 3.86 & 4.8 & 0.28 & - \\
3 & 6.35 & 9.6 & 0.16 & - \\
4 & 11.8 & 17 & 0.12 & - \\
5 & 17.8 & 22 & 0.11 & $1.64 \times 10^{-9}$ \\
6 & 26.8 & 22 & 0.11 & $1.64 \times 10^{-9}$ \\
7 & 34.4 & 22 & 0.11 & $1.64 \times 10^{-9}$ \\
\hline
\end{tabular}

1): amount of dye padded on fabric

2): half fixation time

9): defined in Eq. 2

1): diffusion coefficient calculated from Hill's eq.

Table 3 Kinetic data for fixation of disperse dyes padded on PET-fabric

\begin{tabular}{|c|c|c|c|c|c|}
\hline Dye & $\begin{array}{l}\text { Steaming } \\
\text { solvent }\end{array}$ & $\begin{array}{l}\text { Steaming } \\
\text { temp. } \\
\left({ }^{\circ} \mathrm{C}\right)\end{array}$ & $\begin{array}{c}(D]_{\mathbf{F}}^{\text {Sat } 1)} \\
(\mathrm{g} / \mathrm{kg})\end{array}$ & $\begin{array}{c}\left.k_{0} \cdot 10^{52}\right) \\
\cdot\left(\mathrm{mol} / \mathrm{g} \min ^{1 / 2}\right)\end{array}$ & $\begin{array}{l}\left.K \cdot 10^{28}\right) \\
\left(\min ^{-1}\right)\end{array}$ \\
\hline $1.4-\mathrm{DAAQ}$ & PER & 110 & 10.54 & 0.82 & 4.3 \\
\hline$"$ & $"$ & 100 & 9.28 & 0.39 & 1.3 \\
\hline $1-\mathrm{AAQ}$ & $"$ & 100 & 10.16 & 0.72 & 3.0 \\
\hline$r$ & $"$ & 90 & 8.49 & 0.40 & 1.3 \\
\hline 1 & PER-BuOH & 90 & 9.34 & 0.71 & 2.9 \\
\hline
\end{tabular}
by steaming with saturated vapour of organic solvents.

1): saturation value of fixation

2): defined in Eq. 1

${ }^{8)}$ : defined in Eq. 5 
式と共に(3)式む成立するであろう。して（3)式が成 立寸る条件下では，次の如く(5)式より定数 $K$ 求める ととができる。すなわち(1)柿よび(2)式より，

$$
\begin{aligned}
& D_{\mathrm{F}, t}=2[D]_{\mathrm{F}}^{\text {Sat }}(K / \pi)^{1 / 2} t^{1 / 2} \\
& k_{0}=2[D]_{\mathrm{F}}^{\text {Sat }}(K / \pi)^{1 / 2}
\end{aligned}
$$

従って，図3より(1)式を用いて $k_{0}$ を求如，乙れを(5) 式に代入し，Kが得られる。2 㮔の染料止よ゙溶剂につ いて得られたこれらの值を表 3 に示す。固着速度は1一 AAQ>1.4-DAAQ，また高温>低温で, PER-BuOH (共沸混合液)>PERであった。このような固着速度の差 は染料の性質，浴解度 (表 4) 斿よじ溶剂によるPET瀻

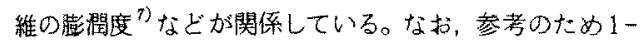
AAQをパッドしたPET織物の各種熱媒体中 $(90 \mathrm{C})$ で の染料の固着速度を比較した結果を図6亿示す。图中の AIRはサーモゾル法で，WATERは一般のスチーミン グ法である。

\section{3 飽和固着量と飽和染着量との比較}

前述したように，蒸熱固着は蒸熱時汇織物化疑樎また は吸収された溶剤が織物に付着している染料を溶解し， 溶解された染料が瀻維内部に固着されるという機構に従 って完了すると仮定する。この仮定下で平衡固着量 $(D)_{\mathrm{F}}$ は浸染の平衡で成立する染浴内染料濃度 $(D)_{\mathrm{S}}$ 上織維内 染料濃度 $[D]_{f}$ 間の分配関係と同じ法則に従って定まる はずである。従って，固着等温線と染着等温線の類倾が 期待できる。また $[D]_{\mathrm{F}}^{\text {Sat }}$ Ł $[D]_{\mathrm{f}}^{\text {Sat }}$ は共に染料の溶解度 および瀻維への親和力により定まるから，西者の值は一 致するはずである。

そてでまず，1-AAQおよび1４４-DAAQのPER㧍よ

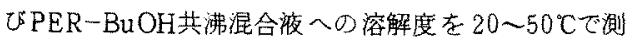
定した。測定については2.4で述心゙た如くで，その結果 加ら外插法で予想した 90〜110 Cでの溶解度を表 4亿示 した。1-AAQでは $30^{\circ} \mathrm{C}$ の飽和液とその $1 / 10$ 濃度溶液 $\sigma \lambda_{\max }$ は変わらないか，分子吸光係数 $\varepsilon$ は前者加約 10 名小さく，さらに低波長領域で $\varepsilon$ がやや大きい事から， 1-AAQD 30 C PER 飽和溶液中には会合染料の存在か

Table 4 Solubilities of 1,4-DAAQ and 1-AAQ in PER and PER-BuOH.

\begin{tabular}{ccccc}
\hline \multirow{2}{*}{ Dye } & \multirow{2}{*}{ Solvent } & Temp. & \multicolumn{2}{c}{ Solubility $(\mathrm{g} / \mathrm{l})$} \\
calc. & measured \\
\hline 1.4-DAAQ & PER & 110 & 2.6 & - \\
" & " & 100 & 2.0 & - \\
1-AAQ & " & 100 & 8.3 & 11.5 \\
" & " & 90 & 6.2 & 7.23 \\
" & PER- BuOH & 100 & 23 & - \\
" & "" & 90 & 18 & - \\
\hline
\end{tabular}

*estimated from the heat of solution $\left(\Delta H_{\text {soln }}\right)$

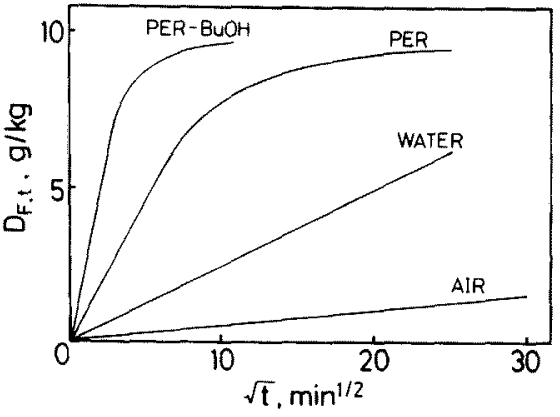

Fig. 6 Effect of steaming media on the fixation rate for 1-AAQ padded on PET fabric (at $\left.90^{\circ} \mathrm{C}\right)$.

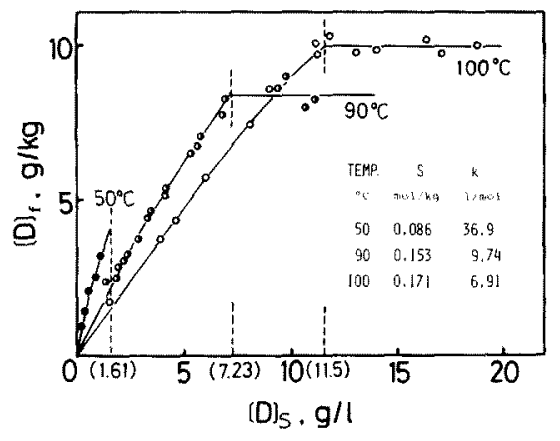

Fig. 7 Adsorption isotherm for 1-AAQ on PET fabric in PER solution and the characteristic values $k$ and $s$ obtained by considering the Langmuir-type isotherm $\left(50^{\circ}, 90^{\circ}\right.$ and $100^{\circ} \mathrm{C}$ ).

暗示された。そしてより高温に於てもG4グラスフィル 多一ろ過法で作成した飽和溶液中认は多少の会合染料が 存在する上考えるべきであるう。

次に染料のPER溶液加らPET繊維への飽和染着量 $\{D]_{\mathrm{f}}^{\text {Sat }}$ 測定する目的で，各種濃度の1-AAQのPER 溶液から製限染浴条件で50，90および 100 ○で PET織物を平衡染色し， $[D]_{\mathrm{f}}$ を求めた。結果 は图7亿示すが、吸着等温線は完全な Nernst 型にはならず，高濃度側では直線からのズレが みられる。このズレは吸着機構がL angmuir型 であるためとも考えられないととはなが，染 浴が私和溶液付近では会合染料者むことによ り活量汃低下し染着量が低くなると予想される こ上，White ${ }^{8)}$ 染染料招よび溶剤が共に同種座 席に吸着するとして導いた理論からは溶郕の吸 着が起とり易い程Langmuir型となりにくいよ 
いう指摘，あるいは非水溶媒系からの分散染料の染着は Nernst 型走示す実験例の多い"ととなどから，乙の場 合は，一応Nernst型心吸着等温線上考えて良いであろ う。 $[D]_{\mathrm{s}}$ がさらに大きくなると $[D]_{\mathrm{f}}$ は一定となり， $[D]_{\mathrm{f}}^{\text {Sat }}$ 㟈められた。と㛫合，曲線の折点の $[D]_{\mathrm{S}}$ は 同蕰で測定した溶解度上一致した。90および $100 \mathrm{C}$ の

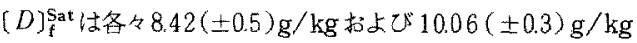
であり. 先に求好を表 30 飽和固着量 $[D]_{\mathbf{F}}^{\text {Sat }}$ と誤差簕囲 内で一政していることが羿められる。同様な結果は $90^{\circ}$ で PER-BuOH共沸混合液による $[D]_{1}^{\text {Sat }}$ ¿ $[D]_{\mathrm{F}}^{\text {Sat }}$ 間 にも認められた。この事は蒸熱処理で織物上儿疑縮ある いは収着された溶剂们浴解した染料と繊維の間には浸染 の場合上同様な平衡関係加成立する事を立証している。

\section{4 平衡固着率について}

平衡固着率を支配する团子について考察しよう。前述 した固着機構加ら考无ると，その一つは蒸熱間化蟣物上 に存在する溶郕量である。

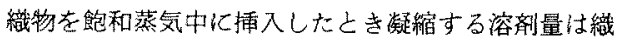
物の温度 $t$ 上溶郕蒸気の温度 $t_{\mathrm{g}}$ の差に比例して決まり， 本実験では挿入織物温度を $80^{\circ} \mathrm{C}$ とたので，蒸気温度と

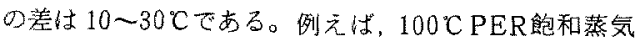
中に播入すれば織物比凝縮するPER量は約 $0.047 \mathrm{l} / \mathrm{kg}$ となり，との値は常温で測定した織物のPER平衡収着 量 $0.056 l / \mathrm{kg}$ ，またHori ら”の㑚定によるPET系の $100{ }^{\circ} \mathrm{C}$ での PER平衡収着量 $0.059 \mathrm{l} / \mathrm{kg}$ に近い值である。 飽和蒸気と平衡状態江るる織物上のPER溶剂量 $S[l\}$ $\mathrm{kg}$ Jの值は高温では明確でない。今，ての值を次のよう 瞋々と。

$S=$ 織物表面溶郕量 $\left(S_{S}\right)+$ 瀻維内部容剂量 $\left(S_{\mathrm{f}}\right)(7)$ ここで， $S_{\mathrm{S}}$ は飽和蒸気之平衡にある糡物の系の表面，

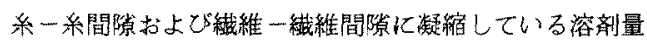
を言う。

さらに、瀻䧽基啠と溶剂間の平衡における染料の分配 関係は,

$$
[D]_{\mathrm{F}}=K[D]_{\mathrm{S}} V
$$

で表わせる。ここで $K$ は分配係数、Vは緎維内部に収着 される溶郕の容靕で(7)式における $S_{\mathrm{f}}$ 亿等しい。

最初織物にパッドした染料濃度 $D_{\mathrm{P}}^{\circ}$ は次式で与えられ。

$$
D_{\mathrm{P}}{ }^{\circ}=[D]_{\mathrm{F}}+[D]_{\mathrm{S}} V+[D]_{\mathrm{S}} S_{\mathrm{S}}
$$

従って，固着率 $(D)_{\mathrm{F}} / D_{\mathrm{P}}^{\circ}$ 休 $(10)$ 式のよう亿表わ女，

$$
[D]_{\mathrm{F}} / D_{\mathrm{P}}^{\circ}=K V /\left\{(K+1) V+S_{\mathrm{S}}\right\}
$$

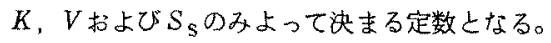

織物上の染料飽和溶液化おいて瀻維基質と分配関係が 成立するに必要な最小付着染料濃度を $D_{\mathrm{P} \text { max }}^{\circ}$ 上する之，

$$
D_{\mathrm{P} \text { max }}^{\circ}=[D]_{\mathrm{F}}^{\text {Sat }}+[D]_{\mathrm{S}}^{\text {Sat }} V+[D]_{\mathrm{S}}^{\text {Sat }} S_{\mathrm{S}}
$$
となり，固著率は(10)式と同様になる。
しかし， $D_{\mathrm{P}}^{\circ}>D_{\mathrm{P} \text { max }}^{\circ}$ においては次式か成立する。 $D_{\mathrm{P}}^{\mathrm{D}}=[D]_{\mathrm{F}}^{\mathrm{Sat}}+[D]_{\mathrm{S}}^{\text {Sat }} V+[D]_{\mathrm{S}}^{\text {Sat }} S_{\mathrm{S}}+[D]_{\mathrm{P}}^{\mathrm{R}}$

こてで，(D) ${ }_{\mathrm{P}}^{\mathrm{R}}$ は平衡に极いて織物上に未溶解のまま 存在する染料量である。檖って，てれを飽和溶解するに 要する溶郕量を $X[l / \mathrm{kg}]$ 之すると，固着率は次の様に なる。

$$
\begin{aligned}
(D]_{\mathrm{F}}^{\mathrm{Sat}} / D_{\mathrm{P}}^{\circ} & =[D]_{\mathrm{F}}^{\mathrm{Sat}} /\left(D_{\mathrm{P}}^{\circ}+[D]_{\mathrm{P}}^{\mathrm{R}}\right) \\
& =K V /\left\{V(K+1)+S_{\mathrm{S}}+X\right\}
\end{aligned}
$$

すなおち， $D_{\mathrm{P}}^{\circ} \leq D_{\mathrm{P} \text { max }}^{\circ}$ では固着率は $D_{\mathrm{P}}^{\circ}$ の值行加加 わらず一定であるが， $D_{\mathrm{P}}^{\circ}>D_{\mathrm{P} \text { max }}^{\circ}$ では $D_{\mathrm{P}}^{\circ}$ の增加と共似 固着率は低下する(图 8 )。图 8 亿は $100^{\circ} \mathrm{C}$ のPER 飽和 蒸気中で 1-AAQパッド織物の平衡固堕について, (13) 式加ら得られる理諭曲線 (実線) 之実験値(O印)を示して ある。この際，V=0.06 l/ $\mathrm{kg}$ の値を仮定し，Kは吸着 等温線から得られる $K V=0.967$ から得た值 $(K=16.1)$ を 用いて計算したが， $S_{\mathrm{S}}=0.002 \mathrm{l} / \mathrm{kg}$ となり，ほぼ 0 に 等しくなった。しかし，90Cの実駼結果より同樣汇求め た結果は $S_{\mathrm{S}}=0.126 \mathrm{l} / \mathrm{kg}$ となり，本実駼結果からの精 度では式(11)より $S_{\mathrm{S}}$ を逆算するととは無理である。

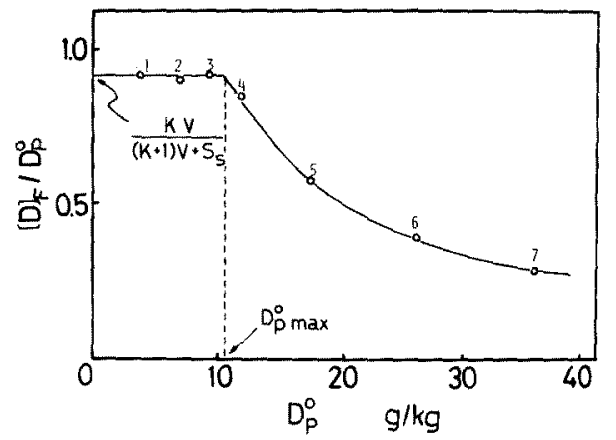

Fig. 8 Relation between equilibrium fixation and amount of dye padded (for the case of $1-A A Q$ in PER saturated vapour at $100^{\circ} \mathrm{C}$ ).

式(10)より，K招よびVが增大すると固着乘は增大 し， $S_{\mathrm{S}}$ が大となると减少する関係が認められる。

DMF 蒸熱の場合の上うに，染料の溶解度が大きく，

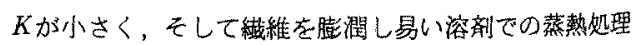
に上る固着率壮低い。しかし，とのような堭合，縄維内 部に含まれる高濃度の染料溶液は乾熱処理に上り，内部 の溶剂のみを蒸発させ，同時に膨润構造を維密化する10,11) ことにより，染料分子を瀻維構造内に効果的に閉じ込め， 高い固着率および堅ろう性が得られたものと考えられる。

\section{4. 結論}

分散染料 1-AAQ拉よび 1，4-DAAQをパッドした PET糡物をPERなどの有機溶剂の飽和蒸気で処理し， 
その固着速度を测定した。その結果，使用した溶剂は染 料の溶解度が比較的高いため織物上に凝縮した溶剂は直 ちに染料を溶解し，付着染料の一部が末溶解のまま織物 上に存在する限り染料の繊維内人の垃散は飽和溶液加ら の哭限染溶条件下で進行することが明らかとなった。 のような機構では初期固着速度は付着染料量に関係なく 一定値を示すが，拡散の進行と共付付着染料量は堿少し 飽和溶液を作执くなる，いわゆるTransitional Diffusion 亿移り固着速度は变化し始好る。

同じ溶剂および温度での1-AAQの飽和固着量上飽和 染着量は一致し、これらの值の一致は蒸熱処理法も浸染 あ其に飽和溶液之瀻維基質間に染料が分配則に従って分 配されるととに依るすのであり，パッドー蒸熱法は超小 浴故の染色工程に等しいと考えられる。

平衡固着率仕分配係数 $K$ ，飽和蒸気上平衡にある緎維 内部溶剤量 $V$ 抢よび瀻維表面凝綰溶剂量 $S_{\mathrm{S}}$ に上って支 配される。そしてPET緎維を膨溜し，かつ染料の溶解 度肪高い溶剂(例えばDMF)による蒸熱処理では染料の 应散仙容易になるが，固着率は低下する。この固着率低 下は蒸熱処理後の乾熱処理によって繊維内部に吸著され た溶剤を蒸発ざせ，同時に溶珴で膨潤し粗となった非晶 領域を緅密化させることにより，迅速少つ高固着率り蒸
熱固着が可能である。

付記：本報の1部は本学会の昭和 55 年年次大会研究 発表会で発表した。なお，研究資の1部は的団法人瀻維 研究協会の助成金に上るもので，同協会に燃謝致します。

\section{女 㣀}

1) H. R. Byland, M. Capponi, H. Gerber and F. Somm; Textilveredlung, 5, 191 (1970)

2）清水 融，木村光雄，関本雅章，五十嵐美雪; 学 振 120 委員会年次報告，24，102（1972）

3）清水 融、本村光雄，林 錦德；ibid，25，153 (1973)

4) M. Nango, S. Takahashi, A. Katayama and N. Kuroki; 瀻学誌, 29, T-296 (1973)

5) R. McGregor and J. N. Etters; Textile Chem. Col., 11, 202 (1979)

6) A. V. Hill; Proc. Roy. Soc, , 104B, 39 (1928)

7) T. Hori, Y. Sato and T. Shimizu; J. Soc. Dyers Col., 97, 6 (1981)

8) H.J. White Jr.; Textile Res. J., 30, $329(1960)$

9) 須田曷男；繊維し工業，4，290(1971)

10) H. D. Weigmann et al.; Text. Res. J., 46, 574 (1976)

11) H. D. Weigmann et al.; ibid., 47, 761 (1977) 